\title{
PROBLEMATYKA ODBUDOWY MIAST W POLSKIM DYSKURSIE PRASOWYM LAT PIERWSZEJ WOJNY ŚWIATOWEJ I WOJNY POLSKO-BOLSZEWICKIEJ
}

\begin{abstract}
Streszczenie. W artykule opisano, jak kwestia odbudowy miast była przedstawiana w prasie Królestwa Polskiego w okresie pierwszej wojny światowej oraz wojny polsko-rosyjskiej. Ten niemal ośmioletni okres charakteryzowało stałe pojawianie się refleksji nad zniszczeniami wojennymi, koniecznością odbudowy tkanki miejskiej zdewastowanej w wyniku działań wojennych oraz przeprowadzenia reformy miast polskich. W dyskursie publicznym tamtych czasów zarysowały się pewne powtarzające się wątki, które można uznać za świadectwo dużej wagi tego problemu dla współczesnych, ale i modernizacyjnego charakteru ich rozterek i komentarzy. Do najważniejszych z nich zaliczyć wypada nacjonalistyczny ton piszących połączony z przekonaniem o potrzebie wypracowania nowego modelu architektonicznego polskiego miasta. Okres ten stanowił zatem podglebie dla rozwoju "stylu dworkowego", charakterystycznego dla architektury publicznej Odrodzonej Rzeczypospolitej.
\end{abstract}

Słowa kluczowe: I wojna światowa, wojna polsko-bolszewicka, zniszczenia wojenne, architektura i urbanistyka XX w., reforma miejska w Królestwie Polskim, II Rzeczpospolita - polityka komunalna

Truizmem byłoby stwierdzenie, że pierwsza wojna światowa ze swoim okrucieństwem oraz niespotykaną wcześniej skalą zniszczeń stanowiła rodzaj szoku dla ówczesnych, przywiązanych do prawie półwiecza pokoju w dobie Belle Époque. Szok ów był tym większy, że konflikt był na bieżąco relacjonowany przez prasę, a obrazy i opisy zniszczeń z frontu docierały do szerokich kręgów opinii publicznej wraz z propagandą wojenną i apelami o społeczną i obywatelską mobilizację․

${ }^{1}$ Vide: A call to arms. Propaganda, Public Opinion and Newspapers in the Great War, ed. T. PADDOCK, Westport, Con.-London 2014. 
Jan Bloch, antycypując okrucieństwo przyszłej wojny europejskiej, tak pisał o stratach, jakie wywołało bombardowanie Paryża w trakcie wojny francusko-pruskiej 1871 r.:

burzenie wiosek i miasteczek, otaczających Paryż, posuwało się dosyć szybko. Nie była też to rzecz drobna zburzyć tyle domów, zniszczyć tyle bogactwa, nagromadzonego przez tyle lat pomyślności bezprzykładnej. Jaki obraz przedstawiały te ruiny! Paryż otoczony jest dookoła pasem wiosek najbogatszych w świecie, dobrze zabudowanych, wesołych, pełnych ludności zamożnej. Trzeba było je zburzyć, aby otworzyć drogę dla armat. Wieść o bombardowaniu Paryża zgrozą przejęła świat cały, gdyż świat cały Paryż uważać musiał za swą własną stolicę. Nauka, talent, praca ludzka nagromadziły tam kopalnię pamiątek, bogactwo, które nie było do odtworzenia - i to wszystko miało, lub przynajmniej mogło, pójsć w gruzy².

Nic dziwnego, że polskiego pacyfistę przerażała wizja ewentualnego oblężenia Warszawy. Pisał bez ogródek, że w razie wojny „trzeba się spodziewać rozbojów i rabunków”, a lotne oddziały piechoty i kawalerii ,jak szarańcza pozostawiają po sobie tylko pustynię"3. Te wyimki z pomnikowej pracy J. Blocha pokazują, że społeczeństwa europejskie początku XX w. zdawały sobie sprawę z tego, z czym wiązałaby się wojna. Pomimo to nie były one, bo i być nie mogły, mentalnie przygotowane na nadciągający kataklizm, który burzył istniejący świat. Dla społeczeństw Europy Środkowej i Wschodniej, marzących o własnej suwerenności, wojna europejska była zarazem szansą, która pozwalała im racjonalizować zniszczenia wojenne jako cenę przyszłej niepodległości. Smutek i żal mieszały się z nadziejami na lepszą przyszłość.

Gdy wojna stała się już faktem, od razu przyniosła ze sobą zniszczenia, których ofiarą padł choćby Kalisz, a także szereg miast i miasteczek znajdujących się w pobliżu frontu. Warszawscy publicyści, początkowo obserwujący przebieg wojny z pewnego oddalenia, z przerażeniem czytali wieści o tragicznym losie kolejnych miejscowości, a także o fali uchodźców zmierzających ku Warszawie z zachodnich rubieży Królestwa Polskiego ${ }^{4}$. „Kurier Warszawski” cytował lokalną gazetę z Łowicza, która relacjonowała:

2 J. BLOCH, Przyszta wojna pod względem technicznym, ekonomicznym i politycznym, t. 4, Warszawa 1900, s. 518-519.

3 Ibidem, s. 529.

${ }^{4} \mathrm{O}$ atmosferze tamtych czasów vide: K. SiERAKOwSKa, Śmierć, wygnanie, gtód w dokumentach osobistych. Ziemie polskie w latach Wielkiej Wojny 1914-1918, Warszawa 2015. 
ciągną przez nasze miasto powozy, platformy, bryki, przepełnione uciekającymi w stronę Warszawy. W popłochu, bardzo często sztucznie wytworzonym, ludzie ci uciekają prawie w tym, w czym stali, nie zdążywszy nawet zabrać cieplejszej odzieży. Widziano dwie młode panienki, lat 14 i 16, przybyłe pieszo z Kalisza, w lekkich kretonowych sukienkach, zziębnięte do kości. Ci, którzy mają jechać do kogo jeszcze, są wytłumaczeni, lecz większość puszcza się, jak to mówią, na cztery wiatry, nie wiedząc dokąd i po co; często bez środków do życias

Pod koniec 1914 r. front znalazł się w bezpośrednim sąsiedztwie stolicy. Największy dziennik wydawany w Warszawie donosił: „spustoszenie Mszczonowa jest nader dotkliwe. Las wycięty na budowę mostów. Mieszkania poniszczone. Wszystkie cenniejsze przedmioty zrabowane" ${ }^{\prime \prime}$. Niemal identycznie wyglądały doniesienia z innych miast. O Rawie Mazowieckiej pisano na przykład, że „opuszczając miasto, Niemcy zrujnowali gmachy rządowe i poniszczyli wewnętrzne ich urządzenia. Ludność jest w okropnej nędzy"7.

Pierwszy rok Wielkiej Wojny nie pozostawił zatem złudzeń. Stało się oczywiste, że konflikt będzie się wiązał z olbrzymim spustoszeniem materialnym miast oraz głodem i nędzą zamieszkującej je ludności. Niespodziewanie obdarowani przez władze w Petersburgu zapowiedzią rychłego wprowadzenia samorządu miejskiego ${ }^{8}$, którego były wcześniej pozbawione miasta Królestwa, dziennikarze i „aktywiści miejscy” z Warszawy szybko zrozumieli, że czeka ich jeszcze jedno arcyważne zadanie: kwestia odbudowy zniszczeń oraz przebudowy istniejących miast w celu sanacji panujących w nich stosunków. $\mathrm{Z}$ tego też powodu niemal natychmiast po wybuchu wojny dyskurs miejski Królestwa Polskiego musiał wejść w nową fazę - dyskusje na temat sanacji miast i panujących w nich stosunków musiały odtąd uwzględnić również kwestię ich powojennej odbudowy ${ }^{9}$.

Nim przejdę do zasadniczej części mych rozważań, wypada pokrótce zarysować pewne ogólne właściwości ówczesnej debaty miejskiej w Królestwie Polskim. Była ona zogniskowana wokół idei samorządu miejskiego, którego

5 Tutacze, „Kurier Warszawski” 1914, nr 274, s. 4.

${ }^{6} Z_{\text {pobojowisk, „Kurier Warszawski” 1914, nr 300, s. } 2 .}$

7 Z pobojowisk, „Kurier Warszawski” 1914, nr 305, s. 3.

8 Vide: S. KoszUTSKi, Nasze miasta a samorzą, Warszawa-Lwów 1915.

9 Niniejszy tekst rozwija wątki, które zasygnalizowałem wcześniej - vide: K. ŚMIECHOWsKI, Kwestie miejskie. Dyskusja o problemach i przysztości miast w Królestwie Polskim 1905-1915, Łódź 2020, s. 262-268. 
- jak wspomniałem powyżej - miasta Królestwa nie posiadały, a który został zapowiedziany tuż przed rewolucją 1905 r., a po opracowaniu przez rząd Stołypina projektu od 1910 r. był przedmiotem prac w Dumie i Radzie Państwa. Dyskusja ta ściśle się zaś łączyła z innymi debatami politycznymi ostatnich lat carskiej Rosji, w tym na temat pogarszających się relacji polsko-żydowskich, umocnienia się Narodowej Demokracji jako głównego rozgrywającego na scenie politycznej, sprawy chełmskiej i innych ${ }^{10}$. Jednocześnie umacniało się przekonanie o fatalnej kondycji miast i potrzebie pilnej interwencji w tej dziedzinie, a do głosu coraz częściej dochodziły utopijne wizje miast-ogrodów Ebenezera Howarda ${ }^{11}$ oraz tendencje nacjonalistyczne $\mathrm{w}$ architekturze i sztuce, konkurujące $\mathrm{z}$ uniwersalistycznymi nurtami estetycznymi i rodzącym się modernizmem $^{12}$. Tuż przed wybuchem wojny wykrystalizował się charakterystyczny, nacjonalistyczny ton, w którym prasa wypowiadała się o miastach i ich pożądanej przyszłości. Miasta polskie, uważane za wyrzut sumienia z powodu ich historycznej słabości, stały się przedmiotem politycznego pożądania, a polskie mieszczaństwo było marzeniem, którego spełnienie miałoby doprowadzić do powstania silnego stanu trzeciego nad Wisłą ${ }^{13}$. Wielce znamienne jest to, co w 1914 r. pisano na temat „polskiego miasteczka” w największym czasopiśmie kulturalnym Królestwa.

Przyjdzie kiedyś czas, który fizjonomię miasteczek Polski, Litwy i Rusi zmieni, przeobrazi, przekształci zupełnie. Wówczas kuty wóz chłopski zadzwoni raźno i wesoło po dobrym bruku i zatrzyma się nie przed kramem żydowskim, ale przed białą, jasną gospodą Towarzystwa współdzielczego

10 Vide: T. Weeks, Poles, Russians and Jews in Conflict. City Government Reform in the Kingdom of Poland, [w:] Nation and State in Late Imperial Russia. Nationalism and Russification on the Western Frontier, 1863-1914, ed. T. WeEks, DeKalb 2008, s. 152-171; P. Trees, Wablen im Weichselland. Die Nationaldemokraten in Russisch-Polen und die Dumawahlen 1905-1912, Stuttgart 2007; K. ŚMIECHOWSKI, op. cit., s. 141-154, 175-178 i 194-232; IDEM, Samorząd miejski jako szansa i zagrożenie dla modernizacji miast w Królestwie Polskim na początku XX wieku, „Rocznik Łódzki” 2017, t. 66, s. 189-205.

11 Vide: A. CzYŻEwski, Trzewia Lewiatana. Antropologiczna interpretacja utopii miasta-ogrodu, Kraków 2001, s. 27-37.

12 Vide: E. Blau, M. Platzer, Shaping the Great City. Modern Architecture in Central Europe, 1890-1937, Münich-London-New York 1999; M. KoHLRAUSCH, Brokers of Modernity East Central Europe and the Rise of Modernist Architects, 1910-1950, Leuven 2019.

13 K. ŚMIECHOWSKI, Kwestie miejskie..., s. 212-224. 
- pisano, roztaczając przed czytelnikami idylliczną wizję, w której ramach:

w miasteczku zjawią się sklepy, jakich dotąd nie ma, i instytucje, jakich brak dotkliwy odczuwa ludność wiejska i małomiejska. Na miejscu zapadłych, brudnych domów staną schludne, murowane budynki szkolne, z których przez otwarte okna wybiegnie na ulice gwar dzieci. Tam, gdzie dzisiaj ciemnota i nędza - odezwie się śmiało głos jutra, głos przyszłości narodu ${ }^{14}$.

Choć widoki na nadejście tej Jutrzenki wydawały się dość ograniczone, sam fakt, że w latach poprzedzających Wielką Wojnę nastąpiła tak poważna zmiana świadomościowa $\mathrm{w}$ postrzeganiu roli i znaczenia miast $\mathrm{w}$ procesie modernizacji kraju, wskazuje, że jeszcze w okresie zaborów na ziemiach polskich miasta urosły do rangi kwestii politycznej, a w polskim obiegu prasowym wykrystalizowała się wyspecjalizowana myśl urbanistyczna ${ }^{15}$. Można zatem powiedzieć, że Królestwo Polskie wkraczało w wojnę z kadrami zdolnymi do podjęcia pogłębionej refleksji nad miastami oraz wypracowania programów ich odbudowy. Składały się na nie trzy środowiska: architekci zajmujący się zawodowo urbanistyką ${ }^{16}$, higieniści walczący o poprawę stanu sanitarnego środowisk miejskich ${ }^{17}$ oraz dziennikarze i szeroko rozumiani „aktywiści miejscy”, którzy gotowi byli wziąć na swe barki opisywanie bieżących problemów miast oraz udział w samorządzie.

Spośród wymienionych wyżej grup najgłośniej o potrzebie odbudowy wypowiedzieli się architekci, dla których stanowiła ona także okazję do wypracowania pewnego programu ideowego. Inżynierowie, silnie osadzeni w dziewiętnastowiecznej dyskusji o „stylu narodowym” w architekturze ${ }^{18}$, popadli w coś w rodzaju fiksacji na punkcie zwalczania obcych naleciałości w wyglądzie miast polskich i uczynienia ich bardziej swojskimi. W grudniu 1914 r., a zatem jeszcze pod rządami Rosjan ${ }^{19}$,

${ }_{14}$ T. I., Miasteczko, „Tygodnik Ilustrowany” 1914, nr 13, s. 250.

${ }^{15}$ E. KIEско, O kilku problemach nowoczesnej budowy miast na ziemiach polskich, [w:] Architektura $w$ mieście, architektura dla miasta. Spoteczne i kulturowe aspekty funkcjonowania architektury na ziemiach polskich, red. M. GETKA-KenIG, A. ŁUPIENKO, Warszawa 2017, s. 29-56.

16 Ibidem.

17 A. ŁuPIENKo, Wktad ruchu higienicznego w polska myśl urbanistyczna (1850-1914), [w:] Architektura w mieście..., s. 57-70.

18 Vide: M. OMILANOwSKa, Nacjonalizm a style narodowe w architekturze europejskiej XIX i początku XX wieku, [w:] Nacjonalizm w sztuce i historii sztuki 1789-1950, red. D. KONSTANTYNów, R. PASIECZNY, Warszawa 1998, s. 145-155; K. STEFAŃSKI, Polska architektura sakralna w poszukiwaniu stylu narodowego, Łódź 2002.

19 Niemcy ostatecznie zajęli Warszawę w sierpniu $1915 \mathrm{r}$. 
„Kurier Warszawski” opublikował odezwę podpisaną przez czołówkę polskich architektów ${ }^{20}$, w której w słowach pełnych patosu odmówiono obcym, zwłaszcza zaś niemieckim wpływom prawa obywatelstwa w architekturze miast polskich. Twórcy odezwy przekonywali, że:

podczas walk, jakie rozegrały się obecnie na ziemiach polskich, zburzona jest ogromna liczba budowli we wsiach i miasteczkach; do ich odbudowy naród przystąpić musi. Zabierając się do tej olbrzymiej i mozolnej pracy, musimy sobie powiedzieć jaka myśl przewodnia będzie nami kierowała, co pozostawimy potomności z czasów tego dziejowego przewrotu ${ }^{21}$.

Z przesadną powagą, w mojej ocenie ocierającą się niemal o śmieszność, wybitni skądinąd architekci twierdzili, że „narzuconemu ziemi naszej, falą naporu teutońskiego, niemieckiemu charakterowi budowli, tak obcemu tradycjom kultury naszej, powinniśmy wypowiedzieć bezwzględną walkę"22.

W wojennym dyskursie nie brakowało i takich wypowiedzi, których autorzy posuwali się do swego rodzaju apoteozy nacjonalizmu. W okupowanej Warszawie antyniemieckie akcenty musiały siłą rzeczy zniknąć z łam prasy, ale za to można było aż nazbyt swobodnie promować wzorce zaczerpnięte ze sztuki ludowej. I tak publicysta „Tygodnika Ilustrowanego” pisał z umiłowaniem o „duchu nacjonalizmu, niosącym mocny pęd nowego życia i nowej sztuki”. Z najostrzejszą srogością wypowiadał się o architektonicznym dorobku XIX stulecia:

te potworne, ciasne i mroczne więzienia, noszące miano dochodowych kamienic wielkomiejskich, (...) te nowe domy w miasteczkach, dzieci duchowe budynków monopolu rządowego lub dworca kolei; (...) te szpitale, jak fabryki; szkoły, jak koszary, te wiejskie plebanie i domy gminne! Oto wyraz przesmutny naszego dorobku w dziedzinie architektury za wiek ubiegły! A jednak lata szły, a my wpatrzeni ciągle w niezdrowe miraże Zachodu i Wschodu, nie spostrzegliśmy robaka, który żarł nam duszę ${ }^{23}$.

Odpowiedzią miała być oczywiście architektura narodowa:

Myśląc dzisiaj w przełomowym momencie o przyszłej odbudowie kraju, powtarzać to sobie muszą, jak pacierz, wszyscy, którzy budować będą - zarówno architekci,

${ }^{20}$ Między innymi Czesław Domaniewski, Józef Dziekoński, Stefan Szyller, Tadeusz Tołwiński.

${ }^{21}$ Odezwa architektów, „Kurier Warszawski” 1914, nr 344, s. 4-5.

${ }^{22}$ Ibidem.

23 J. Wojciechowski, Wieś i miasteczko polskie, „Tygodnik Ilustrowany” 1916, nr 2, s. 16. 
murarze i cieśle, jak i ziemianie i plebani wiejscy, drobni posiadacze i włościanie polscy. Muszą nasycić myśl i oczy kształtami rodzimych budowli tak, iżby wżarły się im one w mózg (sic!), w serce, w krew, w fibrę każdą ${ }^{24}$.

W tak zerojedynkowej wizji przyszłej polskiej architektury, bliższej socrealizmowi niż któremukolwiek z kierunków sztuki zakładającemu wolną ekspresję twórcy, nie było miejsca na jakiekolwiek odstępstwa od prymatu tradycji nad istotą działalności artystycznej. Czy w kraju, gdzie zawsze rywalizowały ze sobą różne wpływy, rzeczywiście istniała tradycja, do której można byłoby łatwo sięgnąć w akcji jego odbudowy?

Zdawano sobie wszelako sprawę, że to wzniosłe zadanie nie będzie łatwe w realizacji. Publicysta „Kuriera Warszawskiego” Wincenty Trojanowski ostrzegał, że kwestia unarodowienia polskiej architektury napotka na wiele problemów praktycznych. Jak dowodził:

tradycja nie istnieje gdyż nie posiadamy ciągłości stanu miejskiego. Jest on zmienny, rekrutuje się przeważnie z coraz to nowych przybyszów, a do tego w większej części obcych nam duchem, obojętnych dla wszystkiego, co nasze, i nieposiadających najmniejszego poczucia piękna, bo nieodczuwających jego potrzeby 25 .

Nie muszę objaśniać, że ów kuriozalny passus dotyczył ludności żydowskiej, która „wznosić będzie dla potrzeb swych wstrętne budy koszarowe, byle taniej i przy tym jak najgorzej"26.

$\mathrm{Na}$ z pozoru tylko przeciwległym biegunie znajdowali się ci architekci i publicyści, którzy upatrywali w wojnie argument za masową budową miast-ogrodów. W obszernym artykule opublikowanym w „Przeglądzie Technicznym” architekt i urbanista Józef Holewiński przekonywał, że ten moment stanowi idealną okazję do podjęcia na szeroką skalę akcji zakładania garden cities:

Obecnie, gdy wojna, przechodząc przez kraj nasz krwawym i ognistym szlakiem, wiele z siedlisk tych obróciła w zgliszcza i gruzy i gdy czeka nas w najbliższej przyszłości mozolna praca odbudowania zniszczonych siedzib, powstaje na nowo nagląca od dawna potrzeba ich gruntownego uzdrowotnienia ${ }^{27}$.

24 Ibidem, s. 17.

25 W. Trojanowski, Odbudowa miast i miasteczek, „Kurier Warszawski” 1915, nr 190, s. 1.

26 Ibidem.

27 J. HolewiŃSKI, Osady ogrodowe wobec zniszczenia przez wojne miast i miasteczek, „Przegląd Techniczny” 1915, nr 3-4, s. 25. 
I dodawał, że:

niezależnie od sprawy odbudowania i uzdrowotnienia istniejących miast i osad, nasuwa się, nie nowa zresztą, myśl zbudowania nowych wzorowych siedlisk, w celu z jednej strony wytworzenia lepszych warunków zdrowotnych i ekonomicznych, z drugiej strony, w celu powstrzymania zbytniego wzrostu istniejących wielkich miast, jak Warszawa i Łódźz ${ }^{28}$.

Józef Holewiński, choć nie miał złudzeń co do możliwości zastąpienia wszystkich zaniedbanych i zniszczonych ośrodków miejskich przez garden cities, nie odżegnywał się bynajmniej od estetycznego nacjonalizmu. W miastach-ogrodach dostrzegł on idealne środowisko do wcielania w życie postulatów z przytoczonej wcześniej odezwy, której był jednym z sygnatariuszy:

artystyczna praca - dowodził - powinna jak najszerzej uwzględniać swojski charakter, swojskie motywy zdobnicze. (...) Tymczasem kraj nasz posiada wiele cennych zabytków budownictwa rodzimego, wiele wzorów o wybitnym piętnie swojakiem; posiadamy pełne wyrazu dwory wiejskie, po miastach charakterystyczne domostwa o podsieniach i attykach, wreszcie posiadamy swojskie budownictwo ludowe, słowem, bogatą skarbnicę, skąd czerpać można motywy rodzime przy wznoszeniu nowych budowli. Ten kierunek w budownictwie, pomyślnie zapoczątkowany już przez naszych architektów, powinien być zaszczepiony na gruncie osady ogrodowej od pierwszej chwili jej powstania ${ }^{29}$.

W prasie okupowanej Warszawy coraz częściej pojawiały się rozliczne pomysły na podkreślenie narodowego charakteru stolicy przez wzniesienie w jej najbardziej zaniedbanych częściach, np. na Powiślu, licznych budowli reprezentacyjnych. Proces przechodzenia od nadziei wolności do otwartego kształtowania się zrębów państwowości polskiej, który rozpoczął się od zapowiedzi wyborów do rad miejskich, a apogeum osiągnął już po Akcie 5 Listopada, jedynie pogłębił zasygnalizowane powyżej tendencje. Antoni Lange, pisarz i publicysta, ponowił swoje tezy opublikowane po raz pierwszy już w 1906 r. w artykule Marzenia warszawskie ${ }^{30}$, w myśl których znienawidzona cytadela miałaby zostać przebudowana na „Akropol, w którym by się mieścił sejm czy parlament, ministerstwa

${ }^{28}$ Ibidem.

29 Ibidem, s. 27.

30 Tekst ten jest omówiony szczegółowo w publikacji: B. ARCisZEWSKA, M. GóRZYŃSKI, Urban Narratives in the Age of Revolutions. Early 20th Century Ideas to Modernize Warsaw, „Artium Quaestiones" 2015, t. 26, s. 101-148. 
itd.”, a pośrodku rynku Starego Miasta, „naszego Krakowa i Norymbergi”, widział „zrekonstruowany dawny ratusz”31.

Wielkie poruszenie wywołał w Warszawie pomysł budowy kopca, który symbolizowałby odzyskanie państwowości. Jak pisano, „nie było dawno projektu, który by Warszawa równie gorąco wzięła do serca" ${ }^{32}$. Problemem była jednak lokalizacja projektowanego kopca. Podczas gdy pomysłodawcy widzieli go na Grochowie, w miejscu bitwy z 1831 r., architekci opowiadali się raczej za lokalizacją w centrum stolicy, nieopodal Cytadeli. Podobnie więc jak u A. Langego to właśnie północna część miasta, symbolizująca dotąd rosyjskie rządy w polskiej stolicy, miałaby ulec transformacji w symboliczną świątynię nowej polskiej państwowości.

W cieniu tych wizji toczyła się realna odbudowa miast doszczętnie zniszczonych w trakcie działań wojennych - Kalisza i Ostrołęki ${ }^{33}$. W pierwszym z tych miast przeprowadzono konkurs architektoniczny, który miał nakreślić kompleksowy plan jego odbudowy. Odbudowy, dodajmy, o tyle ważnej, że dotyczyła ona miasta, które przed wojną ${ }^{34}$ rozwijało się w sposób niezwykle szybki, a jego carskie władze wyobrażały sobie to nadgraniczne miasto jako ośrodek nawet 200-tysięczny ${ }^{35}$. Relacjonując przebieg tego konkursu, architekt K. Jakimowicz podkreślał, że rywalizowały w nim trzy zasadniczo odmienne stanowiska: ,jedni - wdrożeni do liczenia się z dotychczasową gospodarką miast naszych, zdobywają się co najwyżej na korektę istniejącego stanu rzeczy" - pisał, nie bez złośliwości dodając, że inżynierowie ci „trwożliwie, urywkowo, bez jasno wytkniętego celu, obejmującego całość miasta, uzupełniają istniejący plan biurokratyczny nowych części miasta"36.

Odrzucając takie podejście, krytykował jednocześnie tych, którzy

zapatrzeni w przykłady z nauki o budowie miast nowoczesnych, radzi by przekreślić naturalny związek nowych dzielnic ze starymi i na nową modłę nowe miasto według różnych autorytetów książkowych układają ${ }^{37}$.

31 A. WrZESIEŃ, O piękno Warszawy, „Kurier Warszawski” 1916, nr 202 z 23 lipca.

32 Kopiec wolności, „Tygodnik Ilustrowany” 1916, nr 37, s. 439.

33 Za zwrócenie uwagi na casus drugiego z tych miast dziękuję prof. Janowi Salmowi z Politechniki Łódzkiej.

34 Zob. M. PopIOŁeK, German Kalisz: Plans for Reconstruction, [w:] Reconstructions and Modernizations of Historic Towns in Europe in the First Half of the Twentieth Century. Nations, Politics, Society, eds I. BARAŃSKA, M. GÓRZYŃSKI, Kalisz 2016, s. 281-299.

35 Vide: M. GÓRZYŃSKI, Królestwo Polskie i jego papierowe metropolie. Dwa plany regulacyjne miast z okoto 1900 roku: rekonesans badawczy, „Zeszyty Naukowe Kaliskiego Towarzystwa Przyjaciół Nauk” 2017 , t. 17 , s. 164-232.

36 K. Jakimowicz, Odbudowa miast. Kalisz, „Tygodnik Ilustrowany” 1916, nr 16, s. 184.

37 Ibidem. 
Na pochwałę zasługiwali zaś ci artyści:

którzy choć nie obcy zdobyczom, jakie na Zachodzie realna praktyka budowy miast wskazała, w skupieniu wsłuchali się w głosy przeszłości i we współczesne tętno życia rodzimego i rozsnuli obrazy przyszłego Kalisza ${ }^{38}$.

Wychodząc z założenia, że „rozwój miasta winien być ewolucyjny, organiczny”, K. Jakimowicz podkreślał, że „dzielnica staromiejska z typowym rynkiem musi zachować swój dostojny charakter: nie można burzyć gmachów zabytkowych, ani też zatracać kształtu starożytnych ulic", jednocześnie zaś:

nasze zamierzenia odbudowy i regulacji miast muszą uwzględniać zdrowie, szczęście i rozwój jak najszerszych warstw mieszkańców, a dusze ich kształtować się winny pod przemożnym wpływem miasta - jako dzieła sztuki ${ }^{39}$.

$\mathrm{Na}$ tym tle nieco bardziej praktycznie wyglądały działania w Ostrołęce, której odbudowa ruszyła jeszcze w trakcie okupacji. Dziennik „Godzina Polski”, prezentujący stanowisko władz okupacyjnych ${ }^{40}$, podkreślał dobry kierunek, w jakim zmierzała planowana odbudowa mazowieckiego miasteczka. Pisano:

były do wyboru dwie drogi: założenie zupełnie nowej siedziby ludzkiej, choćby nawet dostosowanej do wymagań dzisiejszego życia, lecz nieprzypominającej niczym przeszłości - lub też na podstawie odczucia ducha dawnego wzniesienie - nowego, według dawnych wzorów wyzierających z ruin ${ }^{41}$.

Z powodu akcji wyburzeniowej nad Ostrołęką wisiało widmo spełnienia się tego pierwszego scenariusza, jednak wedle relacji dziennika:

burzenie domów zostało powstrzymane, co, następnie dało możność odbudowywania ich według motywów na wskroś swojskich. (...) Nowe budynki będą mogły być stawiane jedynie z uwzględnieniem planu regulacyjnego miasta - stare zaś, a odpowiednie do odbudowy, w pierwszym rzędzie domy o wybitniejszej wartości architektonicznej będą mogły być odbudowywane w granicach poprzednich ${ }^{42}$.

\footnotetext{
${ }^{38}$ Ibidem.

39 Ibidem.

40 Zob. J. Salm, A Short Contribution to the Post-1914 Reconstruction of Ostrotęka, [w:] Reconstructions and Modernizations..., s. 338-351.

${ }^{41}$ Z Ostrotęki, „Godzina Polski” 1916, nr 299, s. 5.

${ }^{42}$ Ibidem.
} 
Nim rany wywołane działaniami wojennymi z lat 1914-1915 zostały zabliźnione, na ziemie polskie spadł nowy kataklizm w postaci wojny z bolszewicką Rosją. Jak wiadomo, wojna polsko-rosyjska ze względu na swój manewrowy charakter sprzyjała powstawaniu zniszczeń na sporych obszarach. W trakcie ofensywy wojsk rosyjskich z 1920 r. bezpośrednio zagrożone były m.in. Lwów, Zamość, Płock, a Warszawa stanowiła główny cel wojsk Michaiła Tuchaczewskiego. Ostatecznie nie doszło do zniszczenia żadnego z tych miast, bronionych w sporej części przez miejscową ludność ${ }^{43}$. Sposób, w jaki w „Tygodniku Ilustrowanym" pisano o Płocku, był więcej niż sugestywny i pokazywał wprost, jak ewentualne zniszczenie tego zabytkowego miasta zostałoby odebrane przez opinię publiczną doświadczoną wydarzeniami sprzed kilku lat:

najważniejszym szczegółem tej epickiej obrony Płocka jest on sam, Płock, jego nieporównane piękno, jego dostojna starodawność. (...) Stoi ten cud krajobrazu i stylu wysoko nad okolicznym krajem wzniesiony, widny na mile od Wyszogrodu, Włocławka i traktu kutnowskiego. Nowoczesność i tandeta nie zjadły dotychczas Płocka. (...) człowiek, wjeżdżający do Płocka, staje wobec wrażenia, jakby po latach zgiełku przybył do domu kochanego dziadka, gdzie wszystko jeszcze oddycha atmosferą spokoju, osadzonego na wykwintnych obyczajach tradycji ${ }^{44}$.

Ten skrajnie idealistyczny opis mazowieckiego grodu silnie kontrastował z wizją zniszczenia go przez barbarzyńców ze Wschodu (nieważne, że ten sam Płock dopiero co przestał być miastem gubernialnym w... Imperium Rosyjskim):

i ten oto gród od mrocznego średniowiecza już sławny, tysiącem lat zapisany w historii, jeden z najpiękniejszych - co do położenia, jaki widzieć możemy w Europie (sic!), jeden z kilku najprzedniejszych klejnotów zabytkowych w Polsce, żywy i żyjący dokument naszej kultury lechicko-latyńskiej - ten to Płock miał być wdeptany w ziemię stopą wschodniej dziczy, (...) ale ocalał! ${ }^{45}$

Odzyskanie niepodległości i ostateczne zwycięstwo nad bolszewikami oznaczało z jednej strony nasilenie się tendencji do szukania architektury narodowej, z drugiej zaś uświadomienie sobie olbrzymich wyzwań stojących przed odrodzonym państwem. Alfred Lauterbach pisał:

43 Vide: J. Pogonowski, Bój o Lwów (z walk armii ochotniczej z 1920 roku), Gdańsk 1921; G. GoŁęBIEWsKI, Obrona Ptocka przed wojskami bolszewickimi 18-19 sierpnia 1920 r., Płock 2015.

44 A. GrzymąA-Siedlecki, Z pielgrzymki do Ptocka, „Tygodnik Ilustrowany” 1920, nr 39, s. 741.

${ }^{45}$ Ibidem, s. 741-742. 
do rzędu najbardziej wyjaskrawionych przez wojnę zagadnień społecznych należy niezawodnie kryzys wielkich miast wraz z całym sposobem budowania i rozrostu, ze skomplikowanymi przyczynami przeludniania, brakiem i jakością pomieszczeń, warunkami higienicznymi, estetycznymi i moralnymi ${ }^{46}$.

Odpowiedzią miał być jednak już nie pewien rodzaj nacjonalistycznego uniesienia, lecz modernizm, który opierał się na przekonaniu, że „zdrowa i na przyszłość obliczona gospodarka miast musi uzgodnić się z nowoczesnymi wymaganiami i formami życia”’7 Jeśli zaś chodzi o aspekt ideowy, podkreślano konieczność symbolicznej, ale bynajmniej nie nachalnej polonizacji miast polskich. Publicysta Zdzisław Dębicki przekonywał, że:

dusza każdego narodu wypowiada się nie tylko przez poezję, muzykę, rzeźbę i malarstwo, wypowiada się także, często nierównie pełniej i doskonalej, przez kształt architektoniczny, przez linię domu mieszkalnego, pałacu, gmachu publicznego i świątyni ${ }^{48}$.

Co ciekawe, odniesieniem dla autora tych słów były amerykańskie „buildingi”, które w jego optyce symbolizować miały przedsiębiorczego ducha mieszkańców imperium za Wielką Wodą. Niemniej konstatował on, iż:

dawny dwór wiejski, ta ostoja kultury polskiej i tradycji rodzinnej, przestał istnieć czasu tej wojny lub przestanie istnieć niebawem. (...) Dom inny, podmiejski, który mógłby się stać z czasem nowego typu gniazdem rodzinnym i z pokolenia na pokolenie utrwalać przywiązanie do własnego kąta - nie powstał jeszcze. Dlatego, patrząc na Amerykę, na jej dzielnice ogrodowe i country houses, na ich zewnętrzną schludność i wewnętrzne wygody, nie możemy oprzeć się uczuciu upośledzenia i poniżenia ${ }^{49}$.

Kompleks, wyraźnie widoczny w tej wypowiedzi, ilustruje dobrze stan ówczesnej debaty. Prawdziwie polskie miasto, które proponowali futuryści sprzed wieku, jawi się z perspektywy czasu jako środowisko opresyjne, ale jednocześnie na wskroś nowoczesne i odwołujące się do aktualnych wówczas zachodnich wzorców. Sęk w tym, że odrodzone państwo pomimo licznych wysiłków nie było w stanie takiego miasta stworzyć. W „Przeglądzie Technicznym” pisano:

\footnotetext{
46 A. LAUTERBACH, Kryzys miast i nowa architektura, „Tygodni Ilustrowany” 1921, nr 3, s. 42.

7 Ibidem.

48 Z. DęBICKI, Naród a architektura, „Tygodnik Ilustrowany” 1921, nr 2, s. 21.

49 Ibidem, s. 23.
} 
powstające, po wiekowej niewoli, Państwo Polskie, dla swego politycznego i ekonomicznego ugruntowania, wymagać będzie pracy ogromnej i intensywnej, pracy twórczej całego narodu we wszystkich dziedzinach życia społecznego. W zespole tych prac, praca związana $\mathrm{z}$ techniką będzie miała znaczenie pierwszorzędne w rozwoju sił gospodarczych narodu ${ }^{50}$.

Siły te przedstawiały się jednak nader skromnie w stosunku do zamiarów.

Bardzo szybko, bo już u zarania II Rzeczypospolitej okazało się, że styl dworkowy, który z mniejszym lub większym powodzeniem próbowano zastosować do gmachów użyteczności publicznej ${ }^{51}$, został wyparty przez uniwersalistyczny język modernizmu, a marzenia o miastach-ogrodach zastąpiły pierwsze osiedla przeznaczone dla wielorodzinnego budownictwa komunalnego, czerpiące wprawdzie sporo z idei E. Howarda, ale jednocześnie całkowicie zrywające z doktryną osobnego domu dla każdej rodziny, która - jak się wydaje - tak bardzo odpowiadała polskiej duszy, a zarazem równie mocno ignorowała polskie realia ${ }^{52}$. Na dobre i na złe, jedyny realny wzorzec nowoczesności dostępny dla polskich miast w „długim” XX w. był wzorcem korespondującym z Zachodem...

Choć - co starałem się wykazać powyżej - pewien szczególny rodzaj estetycznego nacjonalizmu, jaki dominował $\mathrm{w}$ dyskusjach o odbudowie miast $\mathrm{z}$ lat 1914-1921, ocierał się niekiedy o śmieszność, należy go uznać za zrozumiały odruch w kraju, który wyłaniał się na nowo z mroku dziejów po ponad stu latach niewoli i zaborów. Fiksacja na punkcie „unaradawiania” architektury była zresztą cechą wspólną społeczeństw, które odzyskały państwowość na gruzach imperiów Habsburgów, Romanowów i Hohenzollernów ${ }^{53}$. Już w trakcie Wielkiej Wojny słynny wiedeński architekt Otto Wagner mówił węgierskim architektom, że:

artystyczna ekspresja dzieł architektonicznych musi być podobna w każdym centrum kultury, gdzie styl życia i system sprawowania władzy są do siebie podobne.

50 C. Domaniewski, Politechnika a odrodzenie kraju, „Przegląd Techniczny” 1920, nr 5-8, s. 27.

51 Vide: J. Brodzka, Architekci miasta Łodzi - Wiestaw Lisowski, Łódź 2008, s. 20 i n.; M. PszczóŁKOWsKi, Architektura użyteczności publicznej II Rzeczpospolitej 1918-1939. Forma i styl, Łódź 2014, s. 87 i n.

52 O próbach implementacji idei miast-ogrodów w procesie odbudowy miast Europy po pierwszej wojnie światowej vide: E. BARUCKA, W szkatutach zieleni. Europejski ruch miast-ogrodów 1903-1930, Warszawa 2014, s. 117-168.

53 A. Moravanszky, Competing Visions:. Aesthetic Invention and Social Imagination in Central European Architecture 1867-1918, Cambridge, Mass. 1998, s. 217-284. 
Jeśli zaakceptujemy ten argument, będziemy musieli uświadomić sobie, że coś takiego jak styl narodowy nie istnieje ${ }^{54}$.

W tym samym czasie architekci w Europie Środkowej zdawali się nie robić nic innego, jak tylko szukać najbardziej czeskich, polskich czy węgierskich motywów w architekturze, by ledwie kilka lat później in gremio porzucić te eksperymenty na rzecz modernizmu.

Na koniec warto podkreślić, że dylematy dotyczące odbudowy zniszczonych miast, które ujawniły się z całą mocą w trakcie Wielkiej Wojny i wojny polsko-rosyjskiej, okazywały się zaskakująco podobne do tych, przed jakimi mieli stanąć kierujący akcją odbudowy wielu miast Europy trzy dekady później. Pierwsza z zarysowanych wizji - budowy nowoczesnego miasta na gruzach starego - przypomina logikę, którą kierowano się w Dreźnie. Druga - modernizacji z poszanowaniem lokalnego dziedzictwa - logikę warszawskiego Biura Odbudowy Stolicy po 1945 r. $^{55}$ Oba te podejścia są w sporej mierze racjonalne i znajdują uzasadnienie w konkretnych okolicznościach historycznych. Po pierwszej wojnie światowej w Europie Środkowo-Wschodniej nie było jednak alternatywy dla odwołania się do zmitologizowanych choćby tradycji narodowych jako wyznacznika wzorców estetycznych i ideologicznej nadbudowy nowych państw powstałych na gruzach upadłych imperiów.

\section{BIBLIOGRAFIA}

\section{Prasa}

„Godzina Polski” 1915-1916.

„Kurier Warszawski” 1914-1921.

„Nowy Kurier Łódzki” 1916.

„Przegląd Techniczny” 1914-1921.

„Tygodnik Ilustrowany” 1914-1921.

${ }^{4}$ Cit. per: C.S. MAIER, City, Empire and Imperial Aftermath. Contending Contexts for the Urban Vision, [w:] Shaping the Great City. Modern Architecture in Central Europe, 1890-1937, eds E. BLAU, M. PlatZer, Münich-London-New York 1999, s. 29.

55 Vide: G. PIĄTEK, Najlepsze miasto świata. Warszawa wodbudowie 1944-1949, Warszawa 2020. 


\section{Opracowania}

A Call to Arms. Propaganda, Public Opinion and Newspapers in the Great War, ed. T. Paddock, Westport, Con.-London 2014.

Arciszewska B., Górzyński M., Urban Narratives in the Age of Revolutions. Early 20th Century Ideas to Modernize Warsaw, „Artium Quaestiones” 2015, t. 26, s. 101-148.

Barucka E., W szkatutach zieleni. Europejskiruch miast-ogrodów 1903-1930, Warszawa 2014.

Blau E., Platzer M., Shaping the Great City. Modern Architecture in Central Europe, 18901937, Münich-London-New York 1999.

Bloch J., Przyszta wojna pod wzgledem technicznym, ekonomicznym i politycznym, t. 4, Warszawa 1900.

Brodzka J., Architekci miasta Łodzi - Wiestaw Lisowski, Łódź 2008.

Czyżewski A., Trzewia Lewiatana. Antropologiczna interpretacja utopii miasta-ogrodu, Kraków 2004.

Gołębiewski G., Obrona Ptocka przed wojskami bolszewickimi 18-19 sierpnia 1920 r., Płock 2015.

Górzyński M., Królestwo Polskie i jego papierowe metropolie. Dwa plany regulacyjne miast z okoto 1900 roku: rekonesans badawczy, „Zeszyty Naukowe Kaliskiego Towarzystwa Przyjaciół Nauk" 2017, t. 17, s. 164-232.

Kiecko E., O kilku problemach nowoczesnej budowy miast na ziemiach polskich, [w:] Architektura w mieście, architektura dla miasta. Spoteczne i kulturowe aspekty funkcjonowania architektury na ziemiach polskich, red. M. Getka-Kenig, A. Łupienko, Warszawa 2017, s. 29-56.

Kohlrausch M., Brokers of Modernity East Central Europe and the Rise of Modernist Architects, 1910-1950, Leuven 2019.

Koszutski S., Nasze miasta a samorząd, Warszawa-Lwów 1915.

Łupienko A., Wktad ruchu higienicznego w polska myśl urbanistyczna (1850-1914), [w:] Architektura w mieście, architektura dla miasta. Spoteczne i kulturowe aspekty funkcjonowania architektury na ziemiach polskich lat 1815-1914, red. M. Getka-Kenig, A. Eupienko, Warszawa 2017, s. 57-70.

Moravanszky A., Competing Visions. Aesthetic Invention and Social Imagination in Central European Architecture 1867-1918, Cambridge, Mass. 1998.

Omilanowska M., Nacjonalizm a style narodowe w architekturze europejskiej XIX ipoczatku XX wieku, [w:] Nacjonalizm w sztuce i historii sztuki 1789-1950, red. D. Konstantynów, R. Pasieczny, Warszawa 1998, s. 145-155.

Piątek G., Najlepsze miasto świata. Warszawa w odbudowie 1944-1949, Warszawa 2020.

Popiołek M., German Kalisz: Plans for Reconstruction, [w:] Reconstructions and Modernizations of Historic Towns in Europe in the First Half of the Twentieth Century. Nations, Politics, Society, eds I. Barańska, M. Górzyński, Kalisz 2016, s. 281-299.

Pszczółkowski M., Architektura użyteczności publicznej II Rzeczpospolitej 1918-1939. Forma i styl, Łódź 2014. 
Reconstructions and Modernizations of Historic Towns in Europe in the First Half of the Twentieth Century. Nations, Politics, Society, eds I. Barańska, M. Górzyński, Kalisz 2016.

Salm J., A Short Contribution to the Post-1914 Reconstruction of Ostroteka, [w:] Reconstructions and Modernizations of Historic Towns in Europe in the First Half of the Twentieth Century. Nations, Politics, Society, eds I. Barańska, M. Górzyński, Kalisz 2016. s. $338-351$.

Sierakowska K., Śmierć, wygnanie, gtód w dokumentach osobistych. Ziemie polskie w latach Wielkiej Wojny 1914-1918, Warszawa 2015.

Śmiechowski K., Kwestie miejskie. Dyskusja o problemach i przysztości miast w Królestwie Polskim 1905-1915, Łódź 2020.

Śmiechowski K., Samorząd miejski jako szansa i zagrożenie dla modernizacji miast w Królestwie Polskim na poczattku XX wieku, „Rocznik Łódzki” 2017, t. 66, s. 189-205.

Trees P., Wablen im Weichselland. Die Nationaldemokraten in Russisch-Polen und die Dumawablen 1905-1912, Stuttgart 2007.

Weeks T., Poles, Russians and Jews in Conflict. City Government Reform in the Kingdom of Poland, [w:] Nation and State in Late Imperial Russia. Nationalism and Russification on the Western Frontier, 1863-1914, ed. T. Weeks, DeKalb 2008, s. 152-171.

\author{
Kamil Śmiechowski
}

\title{
THE ISSUE OF THE REBUILDING OF CITIES IN THE POLISH PRESS DISCOURSE DURING THE FIRST WORLD WAR AND POLISH-SOVIET WAR
}

Summary. The subject of this article is the discussion about the rebuilding of cities in the press of the Kingdom of Poland during the First World War and the Polish-Bolshevik war. This almost eight-year period was characterized by the constant appearance of reflection on the devastation of war and the necessity of rebuilding and reforming of Polish cities. In the public discourse of those times, there were some recurring themes that should be considered a testimony to the importance of this problem for contemporary people, but also to the modernizing nature of their dilemmas and comments at the time. The most important of them is the nationalist tone of the writers combined with the conviction that it is necessary to develop a new architectural model of the Polish city. This period was, therefore, a subsoil for the development of the "country house style", so characteristic of the public architecture of the Interwar Poland.

Keywords: First World War, Polish-Bolshevik war, war damages, architecture and urban planning of the 20th century, urban reform in the Kingdom of Poland, II Republic of Poland - communal policy 